\title{
Investigating Dark Fermentation as a Sustainable Organic Waste Management Technology for Producing Biohydrogen From Fruit and Vegetable Waste
}

\section{Primrose Magama ( $\nabla$ magamap@arc.agric.za )}

Agricultural Research Council-Agricultural Engineering (ARC-AE), Pretoria, South Africa. School of Chemical and Metallurgical Engineering, University of Witwatersrand, P/Bag 3, Wits, Johannesburg, 2050, South Africa

\section{Idan Chiyanzu}

Agricultural Research Council-Agricultural Engineering (ARC-AE), Pretoria, South Africa Jean Mulopo

University of the Witwatersrand https://orcid.org/0000-0001-9786-6799

\section{Research}

Keywords: Waste treatment, Biohydrogen, Volatile fatty acids, Dark fermentation, Inoculum pre-treatment

Posted Date: October 18th, 2021

DOl: https://doi.org/10.21203/rs.3.rs-955255/v1

License: (c) (1) This work is licensed under a Creative Commons Attribution 4.0 International License. Read Full License 


\section{Abstract}

Fruit and vegetable waste (FVW) is made up of biodegradable organic compounds whose disposal in landfills leads to water and environmental pollution and the emission of lethal greenhouse gases such as methane. Given the high organic content of FVW and its abundant and constant supply, FVW can serve as valuable feedstock for energy production and other value added bio-commodities. Whilst anaerobic digestion is a mature and proven waste management technology, there is need to investigate and develop other environmentally friendly waste treatment technologies. Dark fermentation is a promising alternative waste treatment technology that can be utilized to generate biohydrogen, however, more R\&D is still required to improve process efficiency and enhance hydrogen yields. This study investigated the production of biohydrogen via dark fermentation using fruit and vegetable waste as a substrate. To enhance hydrogen production the study applied seed inoculum pre-treatment including heat, alkali, acid, and heat-alkali. The results show that FVW can be used as a feedstock for biohydrogen production and that inoculum pre-treatment enhances hydrogen yields. Acid pre-treatment resulted in the highest hydrogen yield $(142,74 \mathrm{Nml} / \mathrm{g}$ VS) and hydrogen content (54\%) while heat pre-treatment generated the lowest hydrogen yield $(0,90 \mathrm{Nml} / \mathrm{g} \mathrm{VS})$. The hydrogen yields of the pre-treatments tested were substantially different $(p<0.001)$. From highest to lowest, the order of pre-treatment efficacy in terms of hydrogen yield enhancement was acid>heat-alkali>alkali>heat. Under all pre-treatments and controls, the main volatile fatty acid (VFA) formed was valeric acid. The maximum valeric acid fraction observed was $86.1 \%$ under acid inoculum pre-treatment.

\section{Introduction}

The production and consumption of fruit and vegetables generates large volumes of organic waste [1, 2]. According to [3], China and India discard up to 100 billion and 5.6 million tons, respectively, of FVW every year. In Europe, fresh FVW accounts for roughly 44 million tonnes of FVW generated annually [4]. South Africa, on the other hand, generates about 4.4 million of FVW per year [5]. The disposal of such high volumes of organic waste through conventional methods such as open dumping and landfilling has several downsides including GHG emissions, environmental pollution and health hazards [6]. This has stimulated research into alternative waste management methods such as Waste to Energy (WtE) technologies, which are viewed as more sustainable and environmentally friendly [6].

Whilst anaerobic digestion (AD) has emerged as a preferred WtE technology, there are a few environmental and economic challenges associated with traditional operation of $A D$ biogas plants. For example, [8] reports that the 2017 market price for electricity was around $30 € / M W h$ while the operating costs for a biogas CHP unit was $25 € / M W h$, indicating low profitability of conventional biogas plants. As a result, there is growing research interest in harvesting the intermediary products of $A D$ including hydrogen and volatile fatty acids (VFAs) instead of methane gas, in a process known as dark fermentation which corresponds to the acidogenesis and acetogenesis stages of $A D$ [9-11]. 
The intermediary products of AD have higher economic value than methane gas, and have a higher market demand owing to a wide range of industrial applications including ammonia synthesis, hydrogenation of edible oils, fertilizer and diesel refining $[12,13]$. This is reflected in the market price of AD products reported by [14]: methane gas (USD 100 - 600 per ton), hydrogen (USD 600 - 1800 per ton) and, VFAs (USD 400 - 2500 per ton). Furthermore, hydrogen is a clean burning fuel as water is the only combustion by-product. Hydrogen also has a high energy density $(122 \mathrm{~kJ} / \mathrm{g})$, which is about 2.75 times higher than that of other hydrocarbon fuels $[12,13]$.

The production of biohydrogen via dark fermentation of FVW is attractive for several reasons which includes that FVW is a low-cost, renewable substrate that is readily available [15]. Compared to chemical processes such as electrolysis and steam reforming of hydrocarbons, dark fermentation is more ecofriendly and sustainable. This is because dark fermentation is not reliant on fossil fuels for feedstock, is less energy intensive, and more cost effective $[15,16]$. There are, however, barriers to practical commercial production of biohydrogen via dark fermentation of organic substrates. One of which is the low hydrogen yields obtained per unit substrate [16]. As a result there are a number of strategies being investigated to achieve improved hydrogen yields including inoculum pre-treatment.

Dark fermentation is a mixed culture system, consisting of various kinds of microorganisms, including hydrogen producing bacteria (HPB), hydrogen consuming bacteria (HCB) and, non- hydrogen producers [17]. During dark fermentation, non-hydrogen producers can compete with hydrogen producing bacteria for substrates, resulting in low hydrogen conversion efficiency. Additionally, HCB can also convert the hydrogen produced during fermentation to other products such as acetate acid via acetogenesis or methane via methanogenesis [17-19]. Therefore, inoculum pre-treatment that selectively inhibits HCB while enriching HBP is essential for enhancing hydrogen yields.

Whilst various research studies are in agreement that inoculum pre-treatment enhances hydrogen production, there is no consensus on the best inoculum pre-treatment method to use [20,21]. According to [22], this is because the efficacy of an inoculum pre-treatment method is affected by numerous physical, chemical and biological factors including substrate type, type of inoculum, and operating conditions. It is therefore necessary to identify the best inoculum pretreatment method for each potential feedstock. Thus, the objective of this study was to evaluate the efficiency of different inoculum pretreatment methods on anaerobic mixed microflora to enhancing hydrogen production of dark fermentation of mixed FVW.

\section{Materials And Methods}

\subsection{Inoculum characteristics and pre-treatment}

Anaerobic sludge collected from a commercial biogas plant situated in Bronkhorstspruit, Pretoria, was used as inoculum for the experiments. The inoculum was characterized for $\mathrm{pH}$, total solid (TS) and volatile solid (VS) content, recorded in Table 1. The pH was measured using the HACH $1682 \mathrm{pH}$ probe, 
while TS and VS were determined according to Environmental Protection Agency (EPA) Method 1684: Total, Fixed, and Volatile Solids in Water, Solids, and Bio solids (EPA, 2001) [23].

Table 1

Substrate and inoculum composition

\begin{tabular}{|llll|}
\hline Parameter & Unit & FVW & Inoculum \\
\hline TS & $\%$ & 11,42 & 2,48 \\
VS & $\%$ & 1,45 & 10,25 \\
VS/TS & $\%$ & 58,76 & 89,75 \\
pH & -- & 6,6 & 8 \\
\hline
\end{tabular}

Prior to dark fermentation, the parent inoculum was subjected to four different pre-treatments (T1-T4) to selectively enrich hydrogen producing mixed microflora. Untreated inoculum was used as a control. The four inoculum pre-treatments are described in Table 2.

Table 2

Description of inoculum pre-treatment applied during the study

\section{Treatment Treatment Procedure \\ Purpose}

T1(Heat) Inoculum was heated at a constant temperature of $90{ }^{\circ} \mathrm{C}$ for 30 min using a pre-heated water bath

T2 The $\mathrm{pH}$ of the inoculum was increased to $\mathrm{pH} 12$ using $4 \mathrm{M}$ (ALKALI) $\quad \mathrm{NaOH}$ and maintained for $24 \mathrm{~h}$. After 24 hours, the initial $\mathrm{pH}$ was readjusted to $\mathrm{pH} 6.5$ using $\mathrm{H}_{2} \mathrm{SO}_{4}(98 \%)$.
Non-spore forming methanogens are destroyed at high temperatures

To impede activity of methanogenic bacteria in mixed consortia due to their low $\mathrm{pH}$ range compared to $\mathrm{H}_{2}$ producers

T3 (Acid) The $\mathrm{pH}$ of the inoculum was lowered to $\mathrm{pH} 4$ using $\mathrm{H}_{2} \mathrm{SO}_{4}$ (98\%) and maintained for $24 \mathrm{~h}$ following. The $\mathrm{pH}$ of the inoculum was lowered to $\mathrm{pH} 4$ using $\mathrm{H}_{2} \mathrm{SO}_{4}(98 \%)$ and maintained for $24 \mathrm{~h}$ following which the $\mathrm{pH}$ was increased to $\mathrm{pH} 6.5$ by adding $4 \mathrm{M} \mathrm{NaOH}$
Activity of methanogens and other nonsporulating bacteria cannot survive at $\mathrm{pH}$ below 6.3 or above 7.8

T4 (Heat- The inoculum was subjected to alkali pre-treatment $(\mathrm{pH} 12)$ ALKALI) followed by heat treatment $\left(90^{\circ} \mathrm{C}\right.$ for $\left.30 \mathrm{~min}\right)$ as described previously

\subsection{Substrate characteristics}

The mixed fruit and vegetable waste (FVW) used in this study was collected from a waste bin at a fruit and vegetable shop. The mixed FVW (Figure 1) consisted mainly of peels, seeds and trimmings of fresh fruit and vegetables left over during the preparation of pre-cut vegetables and fruit salads. Immediately after collection, the FVW was blended using a household electric food blender (Kambrook, 500W Glass 
Jug Blender) to reduce particle size and homogenize the mixture and, thereafter analysed for $\mathrm{pH}, \mathrm{TS}$ and VS content (Table 1). The blended FVW was stored in a freezer at $-20^{\circ} \mathrm{C}$ until time of use wherein the FVW was thawed overnight in a fridge a day before setting up the experiment.

\subsection{Dark fermentation batch tests}

Dark fermentation batch tests were conducted at mesophilic temperature of $37^{\circ} \mathrm{C}$ and ran for 15 days. The study employed the Bioprocess Control Automated Methane Potential Test System (AMPTS II) to run the batch tests. The pre-treated inoculum and fruit and vegetable substrate were weighed and loaded in to $500 \mathrm{ml}$ reactor bottles, at an inoculum (I) to substrate (S) ratio (I/S) of 2 and working volume of 400 $\mathrm{ml}$. The reactor bottles were placed in a heating water bath set at $37^{\circ} \mathrm{C}$ using a 5 row $\times 3$ column experimental layout. A row was assigned for each inoculum pre-treatment type $(5$ rows $=$ control +4 pretreatments), and each pre- treatment was run in triplicates. After loading, the headspace of each reactor was flushed with a carbon dioxide and nitrogen (20/80) gas mixture for a period of one minute to purge oxygen and create an anaerobic environment within the reactors.

\subsection{Analytical Methods}

The methane $\left(\mathrm{CH}_{4}\right)$, hydrogen $\left(\mathrm{H}_{2}\right)$ carbon dioxide $\left(\mathrm{CO}_{2}\right)$ and Oxygen $\left(\mathrm{O}_{2}\right)$ content of the biogas was measured every second day using the NOVA 970P Portable Multi-Gas Industrial Analyser. The portable analyser is equipped with an infrared detector for measuring methane and carbon dioxide, a thermal conductivity detector for hydrogen measurement, as well as an electrochemical sensor for oxygen. The measurement range of the analyser is $0-100 \%$ for all the gases [24].

On the last day of the experiment, Day 15, a $15 \mathrm{~mL}$ aliquot of the reactor broth (digestate) was withdrawn from each pre-treatment (T1-T4) and the control for VFA analysis. The VFAs present in the digestate were analysed using High-Performance Liquid Chromatography (HPLC). The HPLC analyses was conducted following procedures described by [25]. A temperature of $55{ }^{\circ} \mathrm{C}$ under isocratic conditions was used. The mobile phase was made up of $0.005 \mathrm{~mol} / \mathrm{L}$ solution of $\mathrm{H}_{2} \mathrm{SO}_{4}$. The mobile phase solution was filtered using a $0.45 \mu \mathrm{m}$ membrane and degassed before use. The samples were also filtered with a $0.20 \mu \mathrm{m}$ membrane before injection. An injection volume of $20 \mu \mathrm{L}$ and flow rate of $1.0 \mathrm{~mL} / \mathrm{min}$ was used and the VFAs were detected using UV detector at $210 \mathrm{~nm}$.

\subsection{Statistical and Kinetic Analysis}

Statistical analysis of the collected experimental data was conducted using IBM SPSS Statistics 27.0 software package A one-way analysis of variance test (ANOVA) set at a 95\% confidence level $(p<0.05)$ was used to analyse the statistical significance of the inoculum pre-treatments.

\section{Results And Discussion}

3.1 Effect of inoculum pre-treatment on biogas composition over time 
The biogas composition for all treatments varied with time, as shown in the graphs (Figure 2A-E). The biogas composition of the control consisted mainly of methane (40 -62\%) and carbon dioxide gas (23-36 $\%)$. Over the course of the 15-day period, very little hydrogen was detected, as anticipated.

The biogas composition under heat inoculum pre-treatment (T1) comprised of carbon dioxide, methane and hydrogen in varying fractions (Figure $2 \mathrm{~B}$ ). At the beginning of the experiment, carbon dioxide and hydrogen were the main gas fractions at $88 \%$ and $9 \%$ respectively. Nevertheless, there was a shift in gas composition at the end of the experiment with the gas mainly consisting of methane $(77 \%)$ and carbon dioxide $(21 \%)$. Comparing the hydrogen and methane fractions, although the hydrogen content was low (less than $20 \%$ ) it was higher than the methane content up to Day 6, however, beyond Day 6 the hydrogen content dropped while methane increased. This indicates that heat pre-treatment had a short-term positive impact on hydrogen production and partially inhibited methane production for a short period. This is a shortcoming of inoculum pre-treatment, as reported by [26], who stated that pre-treating inoculum to inhibit hydrogen consumers is ineffective in the long run, and that repeated pre-treatment is needed to achieve sustained biohydrogen production. Scholars $[13,27]$ agree that inhibition of hydrogen consuming bacteria can be temporary, adding that spore forming hydrogen consuming bacteria can reactivate after a period of time, forming new stable microbial communities that are adapted to the environment. Researchers [29] ,mention that it is also possible for an inoculum pre-treatment to also suppress non-sporing hydrogen producing bacteria while some sporulating hydrogen consuming bacteria (methane producers) manage to survive the harsh pre-treatment conditions. For example, [23] states that suppression of non-spore forming HPB from the genus Enterobacter can occur while sporulating HCB like Clostridium aceticum and Clostridium thermoautotrophicum can withstand pre-treatment.

In contrast to heat pre-treatment, biogas under alkaline pre-treatment (T2) comprised mainly of carbon dioxide and hydrogen. The carbon dioxide content was high (85\%) at the start of the experiment gradually dropping to $38 \%$. The hydrogen content increased as the experiment progressed reaching a maximum of $48 \%$ on Day 8 , at which point gas production ceased. Throughout the experiment, small quantities of methane (7.5-10.6\%) were observed, indicating that methanogens were not fully inactivated by alkaline pre-treatment. This is similar to the results of [27] who detected small amounts of methane gas during thermophilic dark fermentation of cassava using alkaline pre-treated inoculum.

The biogas generated under acid pre-treatment (T3) consisted mainly of carbon dioxide and hydrogen. However, a lower carbon dioxide content was observed (40-50 \%) compared to pre- treatment T2, and the reaction stopped after only 3 days. The hydrogen content was also higher, ranging between 46 and $54 \%$, the highest hydrogen content observed of all the pre-treatments investigated. Additionally, no or little methane was detected, indicating that acid pre-treatment had fully inhibited the activity of methanogens. In another study, [28] also found negligible methane after acid pre-treatment, concluding that methaneproducing bacteria were effectively inhibited by acid pre-treatment. They further hypothesized that methane-producing bacteria become inactivated when culture environments become too acidic or alkaline, with acidic conditions causing more extreme inhibition. 
Alkali-heat pre-treatment (T4) also produced biogas consisting mainly of carbon dioxide and hydrogen with no methane detected during the 9 day run period. However, a higher carbon dioxide content was observed compared to pre-treatment T3 $(60-84 \%)$ and, the hydrogen content was lower (11-34\%).

\subsection{Effect of inoculum pre-treatment on hydrogen yield}

The cumulative hydrogen yield obtained for each treatment is shown in Figure 3. The graph shows that inoculum pre-treatment had a positive effect on hydrogen production. This is consistent with other research findings [26, 27-30], which found that chemical and physical pre-treatment of the inoculum enhances hydrogen production. Figure 3 also shows that the different inoculum pre-treatments clearly had a varied effect on hydrogen production. This is similar to the observations made by [31-33] who found statistical differences in hydrogen yields between inoculum pre-treatment groups.

Amongst the investigated pre-treatment methods, acid pre-treatment yielded the highest hydrogen yield $(142,74 \mathrm{Nml} / \mathrm{gVS})$, while heat pre-treatment produced the lowest hydrogen yield $(0,90 \mathrm{Nml} / \mathrm{gVS})$. Other works also found that acidic pre-treatment outperformed heat pre-treatment [30, 34]. In comparison, [3537], found inoculum heat pre-treatment to be the most effective way to boost $\mathrm{H}_{2}$ yields from organic waste such as municipal waste, ground wheat and palm oil mill effluent. While several studies have reported increased hydrogen production as a result of heat pre-treatment, literature also suggests that when temperatures above $80^{\circ} \mathrm{C}$ are used, as in this research, hydrogen yields are reduced [38].

\subsection{Effect of inoculum pre-treatment on VFA production}

Numerous studies have shown that dark fermentation hydrogen production is accompanied by the production of VFAs and other low-molecular-weight compounds [25, 30, 33]. Figure 4 depicts the percentage composition of the VFAs produced during the dark fermentation experiments which included acetic, butyric, propionic and valeric.

The main VFA produced in all pre-treatments, including the control, was valeric acid. The highest VFA fraction ( $86 \%$ ) was observed under acid pre-treatment. In general, a high valeric fraction (above 60\%) was observed for pre-treatments that had high hydrogen content (T2 - T4), whereas pre-treatment (T1) with negligible hydrogen production recorded low valeric acid distribution $(\sim 20 \%)$.

The fact that low amounts of acetic/propionic/butyric acid was found in the pre-treatments linked to hydrogen production (T2-T4) was particularly intriguing. This is in stark contrast to other research studies that report that the key metabolites produced during dark fermentation are acetic, propionic and butyric acid [31, 30, 33,].High hydrogen yields are typically associated with butyric and acetic acid production, this is because the metabolic pathways involved in the formation of acetate and butyrate (equations 1and 2) show a positive correlation with hydrogen production and acetate [32]. However, high acetic concentration isn't always associated with high hydrogen volume, as acetic production can result from hydrogen consumption via homoacetogenesis [31].

$\mathrm{C}_{6} \mathrm{H}_{12} \mathrm{O}_{6}+2 \mathrm{H}_{2} \mathrm{O} \rightarrow 2 \mathrm{CH}_{3} \mathrm{COOH}+2 \mathrm{CO}_{2}+4 \mathrm{H}_{2}(1)$ 
$\mathrm{C}_{6} \mathrm{H}_{12} \mathrm{O}_{6} \rightarrow \mathrm{CH}_{3} \mathrm{CH}_{2} \mathrm{CH}_{2} \mathrm{COOH}+2 \mathrm{CO}_{2}+2 \mathrm{H}_{2}(2)$

Glucose Propionic acid Carbon Dioxide hydrogen

\subsection{Comparison of inoculum pre-treatment methods}

To compare the effectiveness of the investigated inoculum pre-treatment methods for enhancing hydrogen production while inhibiting methane production, the hydrogen yield was considered as well as applying one-way ANOVA.

Hydrogen yield

Based on the mean hydrogen yields obtained from this study (Figure 5), the effectiveness of inoculum pre-treatment, ranked in descending order is: Acid >Alkaline- heat>Alkaline>Heat. Comparing the effectiveness of inoculum pre-treatment results obtained in this study other studies (Table 3), no conclusive answer can be given on the best pre-treatment method for enhancing hydrogen production from dark fermentation of FVW. This is because the effectiveness of inoculum pre-treatment is affected by substrate composition, operating conditions and inoculum type amongst other factors [31, 41]. In their works, [31] gave further insight on the variation in results of the best inoculum pre-treatment methods, explaining that the type of substrate affects the effectiveness of the inoculum pre-treatment owing to variances in substrate biodegradability. Moreover, differences in composition of the parent inoculum also influences the effectiveness of a pre-treatment method, further contributing to contradiction in results between studies. This is due to the fact that the microbial communities present in the parent inocula display different levels of tolerance towards changes in environmental conditions, thus inocula responds differently to the harsh conditions they are subjected to by pre-treatments [31]. 
Table 3

Comparison of literature inoculum pre-treatment ranking with study results

\begin{tabular}{|c|c|c|c|c|}
\hline Inoculum & $\begin{array}{l}\text { Investigated pre- } \\
\text { treatment }\end{array}$ & $\begin{array}{l}\text { Most effective } \\
\text { pre-treatment }\end{array}$ & Ranking & Ref \\
\hline $\begin{array}{l}\text { Anaerobic } \\
\text { sludge }\end{array}$ & $\begin{array}{l}\text { Acid, alkali, heat, } \\
\text { heat-alkali }\end{array}$ & Acid & $\begin{array}{l}\text { Acid>heat-alkali>alkali>control } \\
\text { >heat }\end{array}$ & $\begin{array}{l}\text { This } \\
\text { study }\end{array}$ \\
\hline $\begin{array}{l}\text { Activated } \\
\text { sludge }\end{array}$ & $\begin{array}{l}\text { Acid, alkali, BES } \\
\text { heat, aeration, } \\
\text { chloroform }\end{array}$ & Acid & $\begin{array}{l}\text { Acid>alkali>heat> } \\
\text { aeration>chloroform>BES }\end{array}$ & [34] \\
\hline $\begin{array}{l}\text { Anaerobic } \\
\text { granulated } \\
\text { sludge }\end{array}$ & $\begin{array}{l}\text { Chloroform, acid, } \\
\text { alkali, heat, freeze } \\
\text { thaw }\end{array}$ & $\begin{array}{l}\text { Heat }\left(100^{\circ} \mathrm{C} \text {, }\right. \\
\text { 1h) }\end{array}$ & $\begin{array}{l}\text { Heat>alkali>chloro>acid }>\text { freeze } \\
\text { thaw }>\text { control }\end{array}$ & [36] \\
\hline $\begin{array}{l}\text { Anaerobic } \\
\text { sludge }\end{array}$ & $\begin{array}{l}\text { Acid, alkali, } \\
\text { chloroform, heat, } \\
\text { load shocking }\end{array}$ & $\begin{array}{l}\text { Untreated } \\
\text { sludge(control) }\end{array}$ & $\begin{array}{l}\text { Control>load } \\
\text { shock>alkali>heat>acid>chloroform }\end{array}$ & [27] \\
\hline $\begin{array}{l}\text { Anaerobic } \\
\text { mixed } \\
\text { microflora }\end{array}$ & Acid, base, heat & $\begin{array}{l}\text { Heat ( } 800 c, 30 \\
\text { min) }\end{array}$ & Heat $>$ base $>$ acid & {$[38]$} \\
\hline
\end{tabular}

However, this study notes that the majority of studies in Table 3 ranked heat pre-treatment as the most effective method. Similarly, a study paper by [42] concluded that among the pre-treatment approaches they reviewed, heat and acid pre-treatments are the most commonly investigated and most effective. Researchers [43] also stated that heat and acid-base pre-treatments are widely used because they facilitate the proliferation of HPB spores, which are better able to adapt to harsh environmental conditions (high temperature and acidic or basic $\mathrm{pH}$ ) by removing zero spore forming hydrogen consuming bacteria. However, other novel pre-treatment approaches, such as sonication, BESA, or LA addition, have been found to be more successful in other studies [42]. In addition, new technologies including infrared and ionizing irradiation are proving to be more useful for inoculum pre-treatment [43].

While there is no consensus on the best inoculum pre-treatment method, this study and other previous research confirms that inoculum pre-treatment enhances hydrogen production.

Statistical and Kinetic Analysis

ANOVA analysis (Table 4) showed significant differences in the mean hydrogen yield between different pre-treatment groups $(\mathrm{p}<.001)$. The differences were also correlated with variances in metabolic products (VFAs) observed, which could be explained by the diversity of microbial populations. 
Table 4

ANOVA results comparing mean hydrogen yields between pre-treatment groups

\begin{tabular}{|llllll|}
\hline ANOVA & & & & & \\
\hline & Sum of Squares & df & Mean Square & F & Sig. \\
\hline Between Groups & 45180.633 & 4 & 11295.158 & 85.750 & $<.001$ \\
\hline Within Groups & 1317.217 & 10 & 131.722 & & \\
\hline Total & 46497.849 & 14 & & & \\
\hline
\end{tabular}

\section{Conclusion}

The batch dark fermentation results showed that by pre-treating the inocula to selectively enhance hydrogen generating bacteria while suppressing hydrogen consuming methanogens, it is possible to generate hydrogen and VFA from FVW via AD mixed culture fermentation processes. Furthermore, the experimental findings support the study's hypothesis that the AD process can be used to generate a variety of other value-added products in addition to methane, either separately or concurrently. As a result, $A D$ can form an integral part of waste biorefineries of the future.

The pre-treatment methods used for selective enhancement of hydrogen generating bacteria (heat, alkali, acid, heat-alkali) had a major impact on hydrogen yield and VFA composition. The current study concludes that acid pre-treatment was the most effective method for increasing hydrogen yield for the FVW substrate investigated, out of the various inoculum pre-treatments investigated.

\section{Declarations}

\section{Acknowledgements}

The authors are grateful for the funding provided by Agricultural Research Council and support from the University of the Witwatersrand.

\section{Funding}

The authors are grateful for the funding provided by Agricultural Research Council

\section{Conflicts of interest/Competing interests}

The authors have no affiliation with any organization with a direct or indirect financial interest in the subject matter discussed in the manuscript

\section{Availability of data and material}

Data will not be made available upon the journal acceptance 
Code availability

Not applicable

\section{Authors' contributions}

All authors have participated in (a) conception and design, or analysis and interpretation of the data;

(b) drafting the article or revising it critically for important intellectual content; and (c) approval of the final version

\section{Ethics approval}

Not applicable

\section{Consent to participate}

Not applicable

\section{Consent for publication}

Not applicable

\section{References}

1. GFS, 2017. Cambridge Global Food Security. [Online] Available at: https://www.globalfood.cam.ac.uk/events/archivedevents/Fruit_Waste_Valuation. [Accessed 2 May 2017].

2. Gustavsson, J., Cederberg, C. \& Sonesson, U., 2011. Food and Agricultural Organisation of the United Nations. [Online] [Accessed 20 November 2017].

3. Peng, W. \& Pivato, A., 2019. Sustainable Management of Digestate from the Organic Fraction of Municipal Solid Waste and Food Waste Under the Concepts of Back to Earth Alternatives and Circular Economy. Waste and Biomass Valorization, Volume 10, pp. 465-481.

4. Roberts, G., 2018. Resource. [Online] .Available at: https://resource.co/article/17-billion-kg-fruit-andveg-wasted-eu-12788. [Accessed 11 May 2020].

5. WWF-SA, 2017. Food Loss and Waste: Facts and Futures, Johannesburg: WWF-SA.

6. Kumar, A. \& Samadder, S. R., 2017. A review on technological options of waste to energy for effective management of municipal solid waste. Waste Management, Volume 69, pp. 407-422.

7. Sawatdeenarunat, C. et al., 2016. Anaerobic biorefinery: Current status, challenges, and opportunities. Bioresource Technology, Volume 215, pp. 304-313. 
8. Winquist, E., Rikkonen, P., Pyysiainen, J. \& Varho, V., 2019. Is biogas an energy or a sustainability product?- Business opportunities in the Finnish biogas branch. Journal of Cleaner Production, Volume 23, pp. 1344-1354.

9. Kleerebezem, R., Joosse, B., Rozendal, R. \& C, V. L. M., 2015. Anaerobic Digestion Without Biogas?. Environmental Science Biotechnology, Issue 14, pp. 787-801. https://doi.org/10.1007/s11157-0159374-6

10. Wainaina, S., Awasthi, L. \& Taherzadeh, M. J., 2019. Bioengineering of anaerobic digestion for volatile fatty acids, hydrogen or methane production: A critical review. Bioengineered, 10(1), pp. 437458.

11. Bhatt, A., Zhiyong, J. R. \& Tao, L., 2020. Value Proposition of Untapped Wet Wastes: Carboxylic Acid Production through Anaerobic Digestion. iScience, 23(6). https://doi.org/10.1016/j.isci.2020.101221.

12. Ghimire, A. et al., 2015. A Review on Dark Fermentative Hydrogen Production from Organic Biomass: Process Parameters and use of By-Products. Applied Energy, Issue 144, pp. 73-95.

13. De Gioannis, G. et al., 2017. Energy Recovery from One-and- Two Stage Anaerobic Digestion of Food Waste. Waste Management, Issue 68, pp. 595-602.

14. Bastidas-Oyanedel, J. \& Schmidt, J. E., 2018. Increasing Profits in Food Waste Biorefinery-A TechnoEconomic Analysis. Energies, 11(6), pp. 1-14.

15. Cieciura-Włoch, W., Borowski, S. \& Otlewska, A., 2020. Biohydrogen production from fruit and vegetable waste, sugar beet pulp and corn silage via

16. dark fermentation. Renewable Energy, Volume 153, pp. 1226-1237..

17. Mahidhara, G., Burrow, H., Sasikala, C. \& Ramana, C., 2019. Biological hydrogen production: molecular and electrolytic perspectives. World Journal of Microbiology and Biotechnology, 35(116), pp. 1-13.

18. Wang, J. \& Yin, Y., 2017. Principle and application of different pre-treatment methods for enriching hydrogen-producing bacteria from mixed cultures. International Journal of Hydrogen Energy, 42(8), pp. 4804-4823.

19. Manunga, T., Barrios-Perez, J. D., Zaiat, M. \& Rodriguez-Victoria, A., 2019. Evaluation of pre-treatment methods and initial $\mathrm{pH}$ on mixed inoculum for fermentative hydrogen production from cassava wastewater. Biofuels, pp. $1759-7277$.

20. Pachapur, V., Kutty, P., Pachapur, P. \& Brar, S. K., 2019. Seed Pretreatment for Increased Hydrogen Production Using Mixed-Culture Systems with Advantages over Pure-Culture Systems. Energies, 12(3), p. 530.

21. Kothari, R., Kumar, V., Pathak, V. V. \& Tyagi, V. V., 2017. Sequential hydrogen and methane production with simultaneous treatment of dairy industry wastewater: Bioenergy profit approach. International Journal of Hydrogen Energy, 42(8), pp. 4870-4879. https://doi.org/10.1016/j.ijhydene.2016.11.163

22. Srisowmeya, G., Chakravarthy, M. \& Devi, G. N., 2020. Critical considerations in two-stage anaerobic digestion of food waste - A review. Renewable and Sustainable Energy Reviews, Volume 119. https://doi.org/10.1016/j.rser.2019.109587

Page 12/19 
23. Cappai, G. et al., 2018. Biohydrogen Production from Food Waste: Influence of Inoculum to Substrate Ratio. Sustainability, Volume 10, pp. 4506-4521. https://doi.org/10.3390/su10124506

24. EPA, 2001. Method 1684 Total,Fixed, and Volatile Solids in Water, Solids, and Biosolids, Washington: U.S. Environmental Protection Agency Office of Water.

25. NOVA.

26. Vasconcelos de Sa, L. R. et al., 2011. Simultaneous analysis of carbohydrates and volatile fatty acids by HPLC for monitoring fermentative biohydrogen production. International Journal of Hydrogen Energy, 36(23), pp. 15177- 15186.

27. Abubackar, H. N. et al., 2019. Biohydrogen Production from Autoclaved Fruit and Vegetable Wastes by Dry Fermentation under Thermophilic Condition. International Journal of Hydrogen Energy, 44(34), pp. 18776-18784. https://doi.org/10.1016/j.ijhydene.2018.12.068

28. Luo, G., Zou, Z., Wang, W. \& Zhou, Q., 2010. Evaluation of pre-treatment methods on mixed inoculum for both batch and continuous thermophilic biohydrogen production from cassava stillage. Bioresource Technology, Volume 101, pp. 959-964. 10.1016/j.biortech.2009.08.090.

29. Pascualone, M. J., Costa, M. B. \& Dalmasso, P. B., 2019. Fermentative hydrogen production from a novel combination of vermicompost as inoculum and mild heat pre-treated fruit and vegetable waste. Biofuel Research Journal, Volume 23, pp. 1046-1053.

https://doi.org/10.18331/BRJ2019.6.3.5.

30. Pecorini, I., Baldi, F. \& lanneli, R., 2019. Biochemical Hydrogen Potential Tests Using Different Inocula. Sustainability, 11(622), pp. 1-17. https://doi.org/10.3390/su11030622.

31. Mockaitis, G. et al., 2020. Acidic and thermal pre-treatments for anaerobic digestion inoculum to improve hydrogen and volatile fatty anaerobic digestion inoculum to improve hydrogen and volatile fatty acid production using xylose as the substrate. Renewable Energy, Volume 145, pp. 1388- 1398. https://doi.org/10.1016/j.renene.2019.06.134.

32. Rafieenia, R., Pivato, A. \& Lavagnolo, M. C., 2018. Effect of inoculum pre- treatment on mesophilic hydrogen and methane production from food waste using two-stage anaerobic digestion.

International Journal of Hydrogen Energy, 43(27), pp. 12013-12022.

https://doi.org/10.1016/j.ijhydene.2018.04.170.

33. Primasari, B., Tamin, M. \& Mustafa, M. A., 2019. Effects of different pre-treatment methods on anaerobic mixed microflora for hydrogen production and COD reduction from domestic effluent. IOP Conference Series: Materials Science and Engineering, 602(1), pp. 1-8.

34. Magrini, F. E. et al., 2020. Effect of different heat treatments of inoculum on the production of hydrogen and volatile fatty acids by dark fermentation of sugarcane vinasse. Biomass Conversion and Biorefinery, pp. 1-14.

35. Chang, S., Li, J. \& Liu, F., 2011. Evaluation of different pre-treatment methods of preparing hydrogenproducing seed inocula from waste activated sludge. Renewable Energy, 35(6), pp. 1517-1522. https://doiorg/10.1016/j.renene.2010.11.023. 
36. Zhenhong, D. L., Yongming, S. \& Longlong, M., 2010. Evaluation of pretreatment methods on harvesting hydrogen producing seeds from anaerobic digested organic fraction of municipal solid waste (OFMSW). International Journal of Hydrogen Energy, Volume 35, pp. 8234-8240. https://doi.org/10.1016/j.ijhydene.2009.12.058.

37. Mohammadi, P., Ibrahim, S. \& Annuar, M. S. M., 2012a. Comparative study on the effect of various pretreatment methods on the enrichment of hydrogen producing bacteria in anaerobic granulated sludge from brewery wastewater. Korean Journal of Chemical Engineering, Volume 29, pp. 13471351. https://doi.org/10.1007/s11814-012-0018-z.

38. Argun, H. \& Kargi, F., 2009. Effects of sludge pre-treatment method on bio- hydrogen production by dark fermentation of waste ground wheat. International Journal of Hydrogen Energy, Volume 34, pp. 8543-8548.

39. Wang, J. \& Wan, W., 2008. Comparison of different pre-treatment methods for enriching hydrogenproducing bacteria from digested sludge. International Journal of Hydrogen Energy, 33(12), pp. 29342941.https://doi.org/10.1016/j.ijhydene.2008.03.048.

40. Akinbomi, J. \& J, T. M., 2015. Evaluation of fermentative hydrogen production from single and mixed fruit wastes. Energies, Volume 8, pp. 4253-4272.

41. Cahyari, K., Putri, Hidayat, M. A. \& Norajsha, J. D., 2018. Biohydrogen Production from Pineapple Waste: Effect of Substrate Concentration and Acid Pre-treatment. Materials Science and Engineering, Volume 358, pp. 1-5.

42. Salem, A. H., Brunstermann, R., Mietzel, T. \& Widmann, R., 2018. Effect of pre-treatment and hydraulic retention time on biohydrogen production from organic wastes. International Journal of Hydrogen Energy, Volume 43, pp.4856-4865. https://doi.org/10.1016/j.ijhydene.2018.01.114.

43. Bundhoo, Z. M. \& Hassan, M. A., 2015. Effects of pre-treatment technologies on dark fermentative biohydrogen production: A review. Journal of Environmental Management, Volume 157, pp. 2048.https://doi.org/10.1016/j.jenvman.2015.04.006.

44. Dessi, P., Porca, E. \& Frunzo, L., 2018. Inoculum pre-treatment differentially affects the active microbial community performing mesophilic and thermophilic dark fermentation of xylose. International Journal of Hydrogen Energy, 43(19), pp. 9233-9245. https://doi.org/10.1016/j.jjhydene.2018.03.117

\section{Figures}




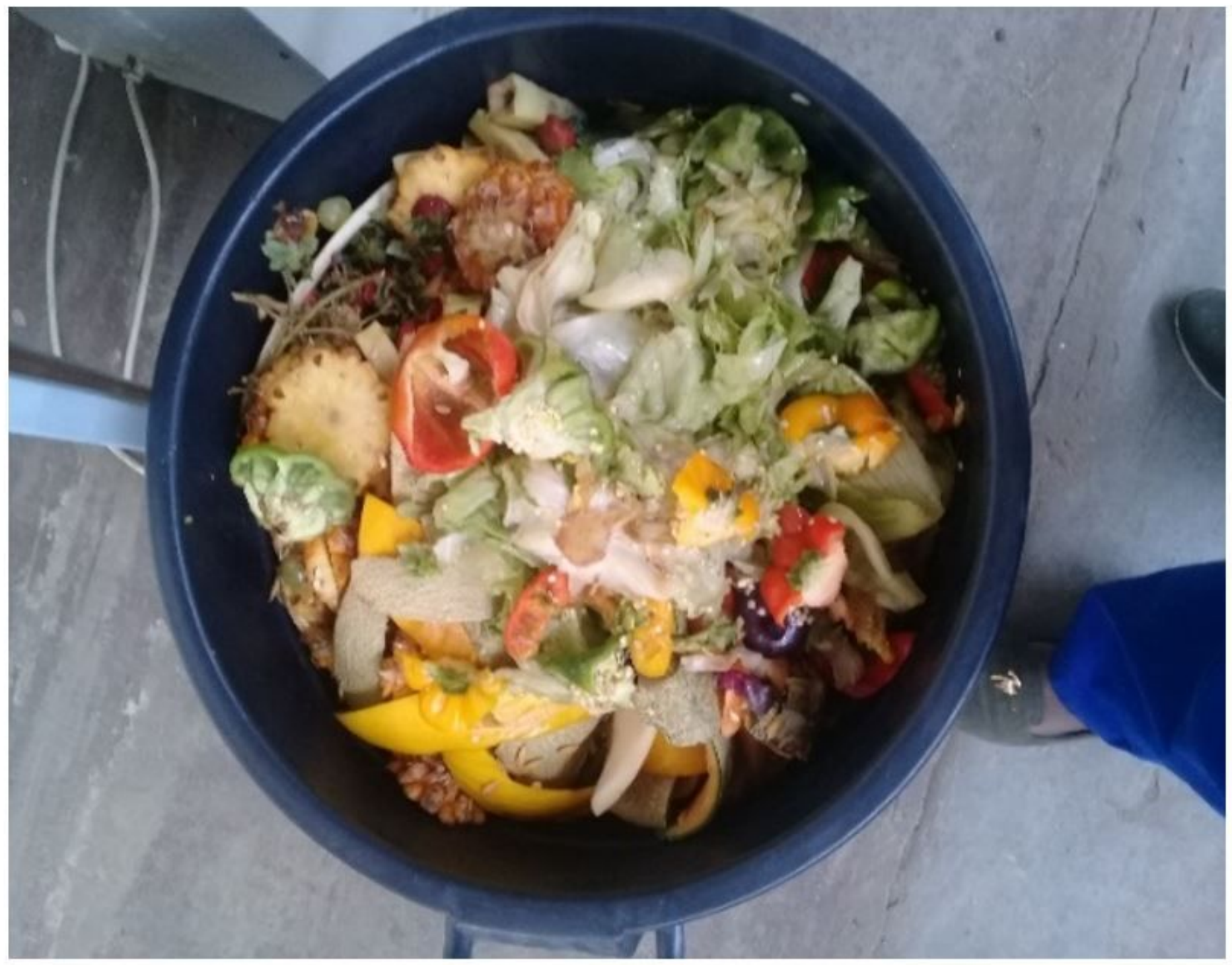

Figure 1

Fruit and vegetable waste used as substrate 


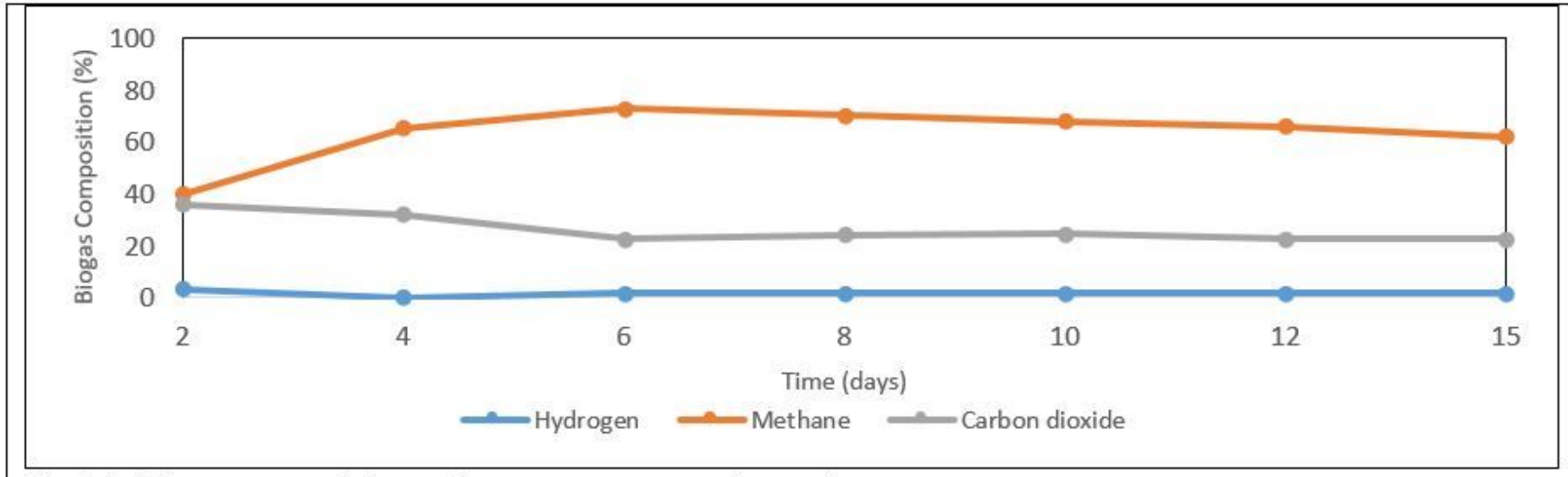

Fig 2A: Biogas composition under no pre-treatment (control)

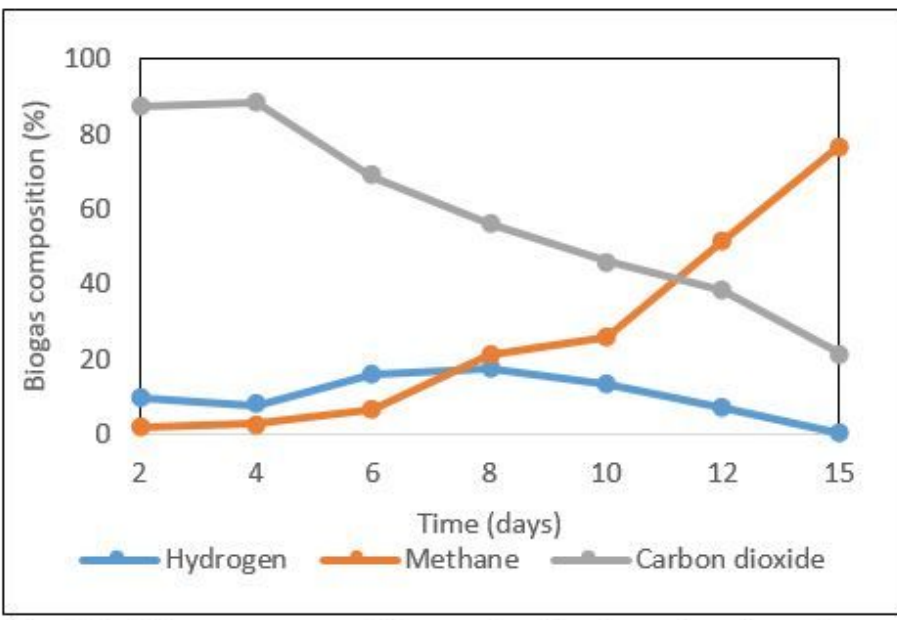

Fig 2B: Biogas composition under heat pre-treatment

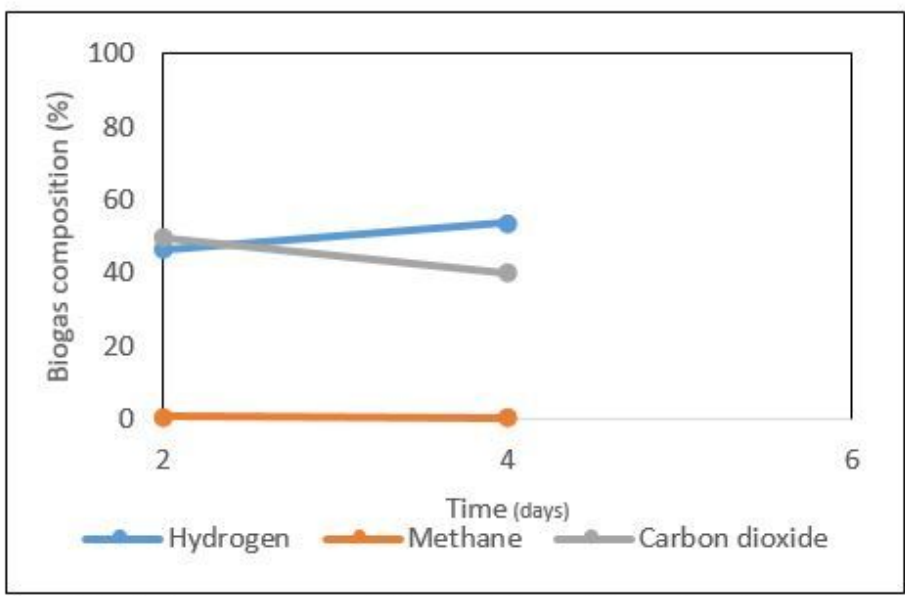

Fig 2D: Biogas composition under acid pre-treatment

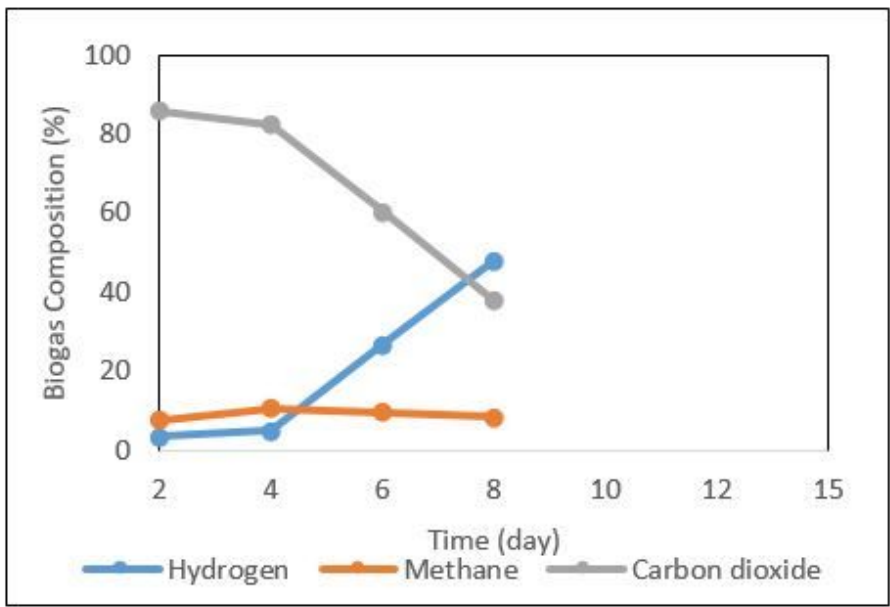

Fig 2C : Biogas composition under alkali pre-treatment

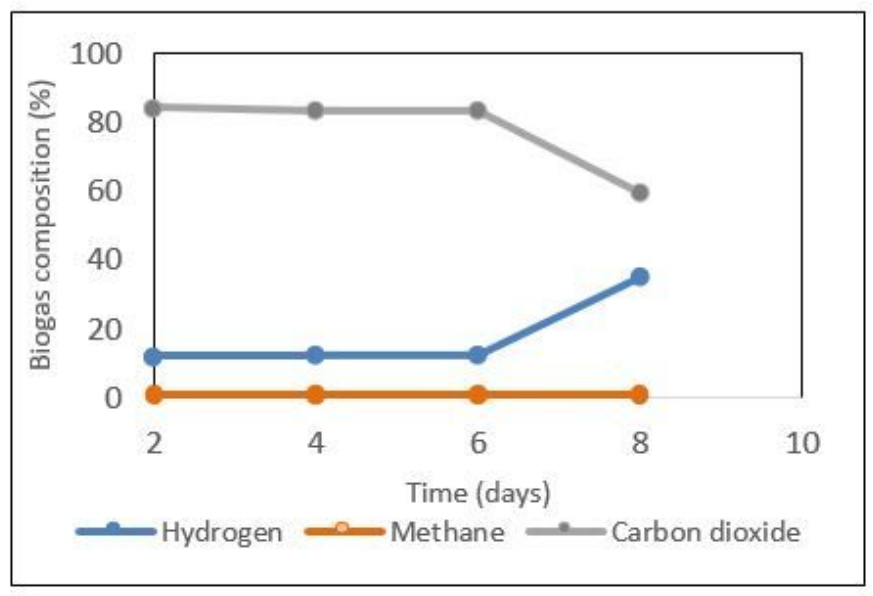

Figure 2E: Biogas composition under heat-alkali pretreatment

\section{Figure 2}

(A-E) Biogas composition under different inocula pre-treatments from Day 


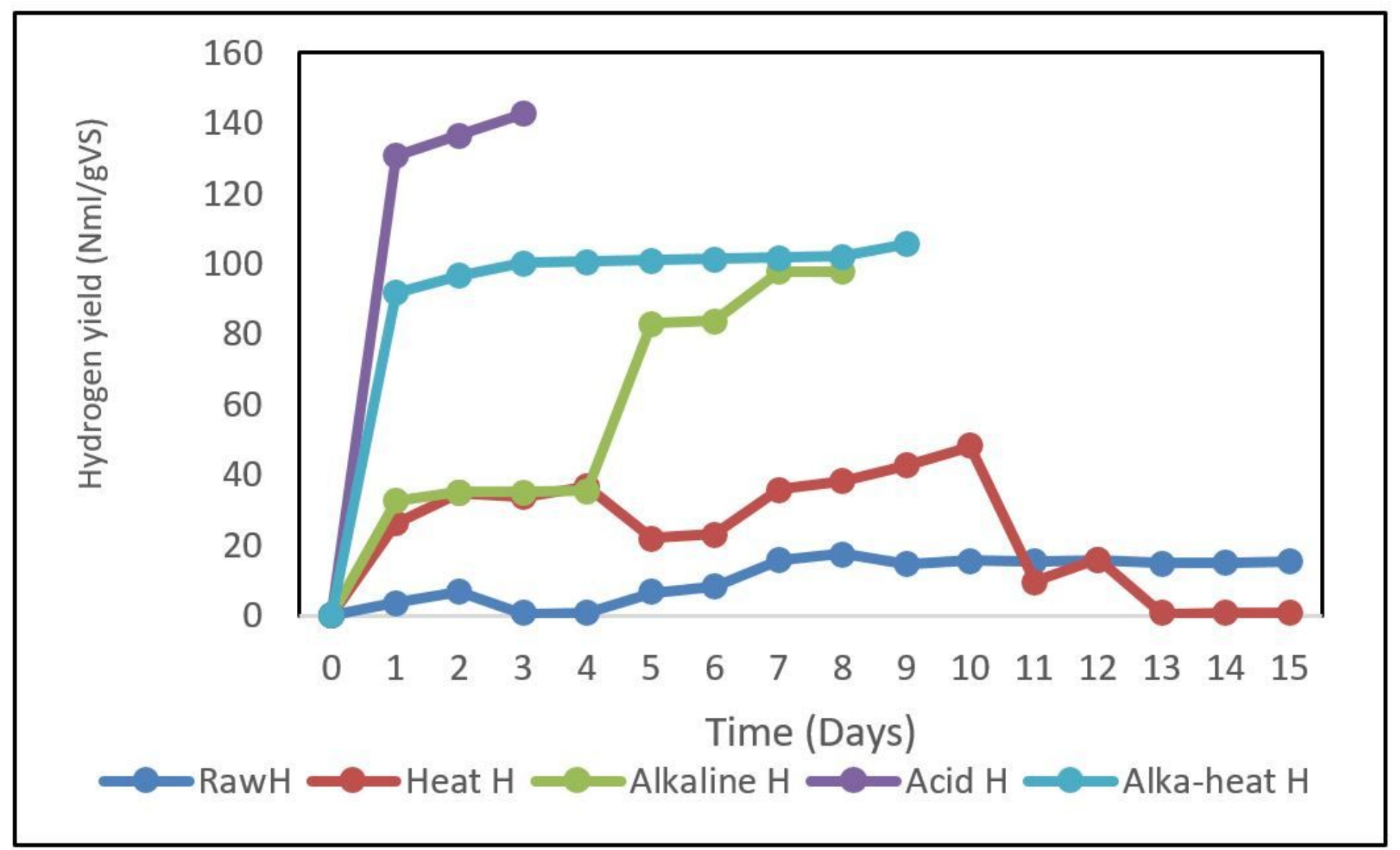

Figure 3

Time profile cumulative hydrogen yield for the different inoculum pre-treatments 


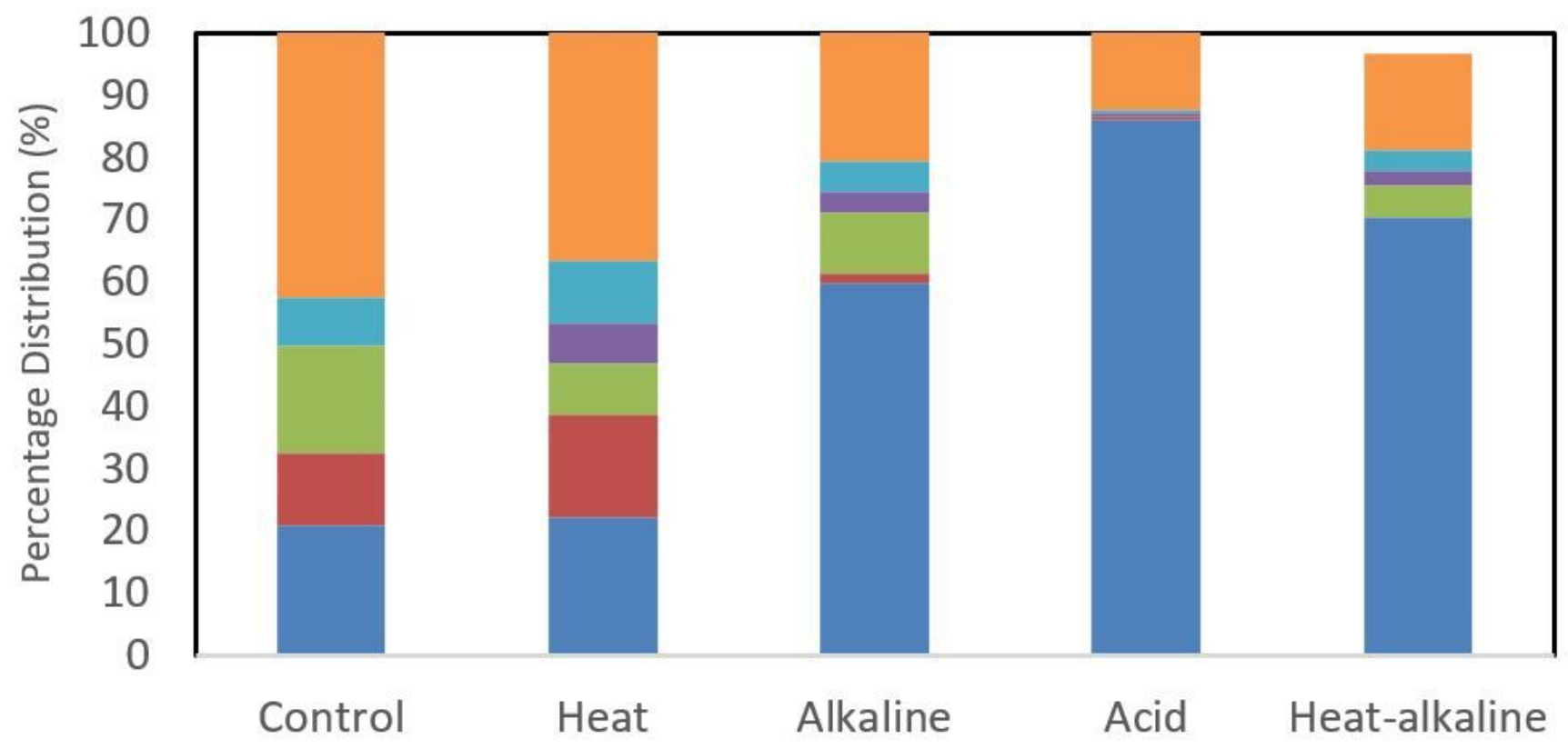

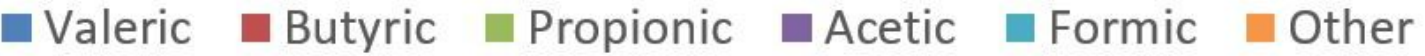

Figure 4

Composition of VFA generated under various inoculum pre-treatment methods 


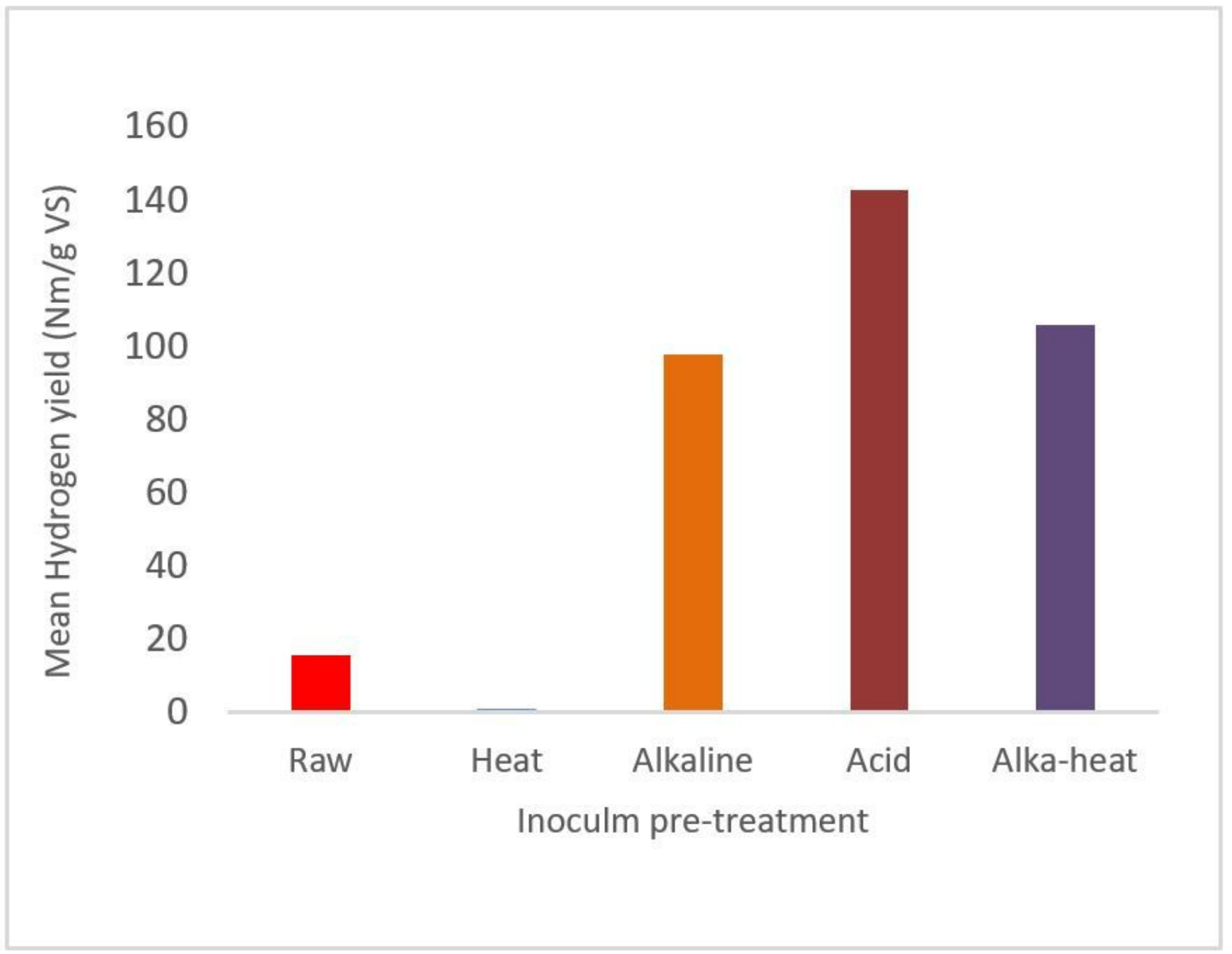

Figure 5

Mean hydrogen yield as a function of pre-treatment

\section{Supplementary Files}

This is a list of supplementary files associated with this preprint. Click to download.

- GraphicalAbstract.docx 